\title{
VARIABLE COSTING SEBAGAI ALTERNATIF COSTING UNTUK MENINGKATKAN KUALITAS KEPUTUSAN PENENTUAN HARGA PRODUK
}

\section{Linda Santioso ${ }^{1}$, Susanto Salim ${ }^{2}$, Andreas Bambang Daryatno ${ }^{3}$ dan Nurainun Bangun ${ }^{4}$}

\author{
${ }^{1}$ Program Studi S1 Akuntansi Universitas Tarumanagara,Jakarta \\ Email:linda.santioso@gmail.com \\ ${ }^{2}$ Program Studi S1 Akuntansi Universitas Tarumanagara, Jakarta \\ Email:stsalim@yahoo.com \\ ${ }^{3}$ Program Studi S1 Akuntansi Universitas Tarumanagara, Jakarta \\ Email:bambangandreas@gmail.com \\ ${ }^{4}$ Program Studi S1 Akuntansi Universitas Tarumanagara, Jakarta \\ Email:inun66@yahoo.com
}

\begin{abstract}
ABSTRAK
Salah satu alat untuk meningkatkan kualitas pengambilan keputusan melalui variable costing. Melalui kegiatan penentuan harga produk melalui variable costing diharapkan setiap aktivitas kegiatan perusahaan dapat terpakai dengan maksimal dan terkendali dengan baik. Target khusus yang ingin dicapai melalui pendampingan adalah penyusunan dan implementasi penentuan harga produk melalui variable costing untuk meningkatkan kualitas pengambilan keputusan. Metode yang dipakai dengan memberikan penyuluhan dan pelatihan penyusunan teknik perhitungan dan pemilahan biaya variable dan biaya tetap. Untuk meningkatkan kinerja perusahaan maka kami selaku dosen di Jurusan Akuntansi Fakultas Ekonomi Universitas Tarumanagara akan mengajukan ke manajemen PT Kapur Putih Lampung untuk memberikan penyuluhan dan lokakarya di unit usaha perusahaan dengan judul "Variable Costing sebagai alternatif costing untuk meningkatkan kualitas keputusan penentuan harga produk".

Kata Kunci: Variable costing, Alternatif costing, Penentuan harga produk, Pengambilan keputusan.
\end{abstract}

\section{PENDAHULUAN}

PT Kapur Putih Lampung pusatnya berlokasi di Bandar Lampung Office, factory Negri Katon Pesawaran yang memproduksi produk-produk keramik dan mempunyai unit usaha didaerah Gading Serpong Tangerang. Kami mengadakan pertemuan dengan manajemen unit usaha PT Kapur Putih Lampung dan sekalian survey lapangan, di Ruko L'AGRICOLA Blok C/20 Gading Serpong Curug Sangereng Kelapa Dua Tangerang dan Aktifitas ini hanya diberikan kepada perwakilan masing-masing bagian di internal perusahaan di PT Kapur Putih Lampung.

Berdasarkan pertemuan kami dengan pihak manajemen, maka dapat kami ketahui keadaan dari unit usaha PT Kapur Putih Lampung bahwa selama ini, Pengambilan keputusan dalam penentuan harga produk berdasarkan metode full costing (pendekatan traditional) yaitu penentuan harga pokok produksi yang memperhitungkan semua unsur biaya produksi ke dalam harga pokok produksi yang terdiri dari biaya bahan baku, biaya tenaga kerja langsung dan biaya overhead pabrik baik yang bersifat variabel maupun tetap ditambahkan margin tertentu yang di tetapkan oleh manajemen. Perusahaan seringkali mengalami masalah dalam pengambilan keputusan dalam menentukan harga jual produk mengingat persaingan bisnis yang semakin ketat dan serbuan impor barang-barang keramik. Hal ini mengakibatkan terjadinya penurunan penjualan, yang secara otomatis menurunkan kapasitas produksi sehingga menimbulkan beberapa produk dalam produksi mengalami idle produksi. Untuk itu kami merasa perlu, adanya suatu alat untuk menghindarkan idle produksi dengan kualitas pengambilan keputusan tepat sehingga laba perusahaan tetap terkendali melalui Variable Costing sebagai alternatif costing untuk meningkatkan kualitas keputusan penentuan harga produk. 
Dengan melakukan pengambilan keputusan yang tepat maka jika ada idle produksi, manajemen dapat mempunyai alternatif dalam pengambilan keputusan dan tidak hanya terpaku dengan caracara traditional (full costing) saja. Dengan demikian semua pengambilan keputusan dalam penentuan harga jual produk mampu mereduksi unsur ketidakpastian yang dihadapi oleh perusahaan. Sebagai tindak lanjut dari pertemuan dengan pihak manajemen PT Kapur Putih Lampung, kami mengambil kesimpulan perusahaan masih memerlukan suatu tindakan lanjut berupa penyuluhan dan pelatihan dalam Variable Costing sebagai alternatif costing untuk meningkatkan kualitas keputusan penentuan harga produk. Dengan adanya alternatif costing dalam penentuan harga jual produk diharapkan operasional dan aktifitas perusahaan dapat ditingkatkan dengan lebih baik.

Sasaran dari aktivitas penyuluhan, pelatihan, pendampingan bagi perusahaan ini, dapat dijadikan model kerja bagi manajemen perusahaan baik bagian Penjualan, Produksi, Akuntansi (cost Accounting) perusahaan-perusahaan manufaktur yang mengalami idle kapasitas produksi dan alternatif costing untuk meningkatkan kualitas keputusan penentuan harga produk. Sedangkan target dari aktivitas penyuluhan bagi Fakultas Ekonomi yaitu untuk dapat dijadikan modul bagi pengajaran atau referensi tambahan bagi mata kuliah " Akuntansi Biaya dan Akuntansi Manajemen " khususnya Variable Costing sebagai alternatif costing untuk meningkatkan kualitas keputusan penentuan harga produk bagi mahasiswa jurusan Akuntansi.

Untuk Mahasiswa diharapkan dapat menjelaskan bagaimana melakukan alternatif pendekatanpendekatan costing, yaitu melalui metode Full Costing dan Variable Costing

Dengan adanya penyuluhan dan pembinaan penyusunan Variable Costing ini diharapkan muncul sinergi yang lebih nyata antara dunia pendidikan dan dunia bisnis sehingga kedua belah pihak mendapatkan manfaat untuk kemajuan bersama.

\section{METODE PELAKSANAAN}

Metode pelaksanaan kegiatan dilakukan dengan penyuluhan dan pelatihan mengenai Variable Costing sebagai alternatif costing untuk meningkatkan kualitas keputusan penentuan harga produk. Selain itu kami juga akan melakukan pendampingan implementasi di setiap analisa seperti metode costing melalui pendekatan Full costing dan Variable costing beserta keunggulan dan kelemahan dari ke dua pendekatan diatas.. Untuk mendukung implementasi ini, akan dibuatkan pedoman dasar dan sederhana dalam penentuan dan pengelompokan biaya tetap dan variabel berdasarkan literatur maupun contoh kasus bagaimana untuk membuat, menganalisa sampai dengan pengambilan keputusan dalam penentuan harga jual produk.

Hal ini diharapkan memberikan manfaat bagi internal perusahaan untuk mengurangi tingkat kesalahan dalam pengambilan keputusan dan meningkatkan efektivitas dan efisiensi perusahaan, membuat karyawan dapat bekerja dengan lebih pasti, kapasitas produksi dapat terjaga dengan lebih baik, yang akhirnya tujuan perusahaan dapat tercapai.

Pelaksanaan penyuluhan dilakukan pada tanggal 20 \& 27 April 2019 bertempat di Gading Serpong-Tangerang.

Luaran hasil pelatihan ini berupa modul yaitu modul Variable Costing Sebagai Alternatif Costing Untuk Meningkatkan Kualitas Keputusan Penentuan Harga Produk yang akan digunakan bagi PT Kapur Putih Lampung sebagai pedoman mereka untuk meningkatkan kinerja perusahaan dan meningkatkan kualitas pengambilan keputusan dalam penentuan harga pokok produk sehingga diharapkan dapat meminimalkan kesalahan yang terjadi dalam menentukan harga jual produk. 


\section{Metode Penentuan Harga Pokok Produksi}

Metode penentuan harga pokok produksi adalah cara untuk memperhitungkan unsur-unsur biaya kedalam harga pokok produksi. Dalam memperhitungkan unsur-unsur biaya ke dalam harga pokok produksi, terdapat dua pendekatan yaitu Full costing dan Variabel costing. (Garrison, Nore,\& Brewer, 2001)

a. Full Costing. Full costing merupakan metode penentuan harga pokok produksi yang memperhitungkan semua unsur biaya produksi ke dalam harga pokok produksi yang terdiri dari biaya bahan baku, biaya tenaga kerja langsung dan biaya overhead pabrik baik yang berperilaku variabel maupun tetap. Pendekatan Full costing yang biasa dikenal sebagai pendekatan tradisional menghasilkan laporan laba rugi dimana biaya-biaya di organisir dan sajikan berdasarkan fungsifungsi produksi, administrasi dan penjualan. Laporan laba rugi yang dihasilkan dari pendekatan ini banyak digunakan untuk memenuhi pihak luar perusahaan, oleh karena itu sistematikanya harus disesuaikan dengan prinsip akuntansi yang berlaku umum untuk menjamin informasi yang tersaji dalam laporan tersebut.

b. Variable Costing. Variable costing merupakkan metode penentuan harga pokok produksi yang hanya memperhitungkan biaya produksi yang berperilaku variabel ke dalam harga pokok produksi yang terdiri dari biaya bahan baku, biaya tenaga kerja langsung dan biaya overhead pabrik variabel.Dalam pendekatan ini biaya-biaya yang diperhitungkan sebagai harga pokok adalah biaya produksi variabel yang terdiri dari biaya bahan baku, biaya tenaga kerja langsung dan biaya overhead pabrik variabel. Biaya-biaya produksi tetap dikelompokkan sebagai biaya periodik bersama-sama dengan biaya tetap non produksi.

Pendekatan Variable costing di kenal sebagai Contribution approach merupakan suatu format laporan laba rugi yang mengelompokkan biaya berdasarkan perilaku biaya dimana biaya-biaya dipisahkan menurut kategori biaya variabel dan biaya tetap dan tidak dipisahkan menurut fungsifungsi produksi, administrasi dan penjualan. Dalam pendekatan ini biaya-biaya berubah sejalan dengan perubahan output yang diperlakukan sebagai elemen harga pokok produk. Laporan laba rugi yang dihasilkan dari pendekatan ini banyak digunakan untuk memenuhi kebutuhan pihak internal oleh karena itu tidak harus disesuaikan dengan prinsip akuntansi yang berlaku umum.

\section{Full Costing vs Variable Costing}

Menurut Mulyadi (2010) Full costing dan Variable costing pada dasarnya merupakan metode yang berkaitan dengan penentuan harga pokok produksi. Dalam metode Full costing menentukan harga pokok produksi yang dimana semua biaya produksi diperhitungkan ke dalam harga pokok produksi. Hal tersebut menunjukkan bahwa metode Full costing ini tidak membedakan antara biaya produksi variabel dan biaya produksi tetap karena akan dimasukkan ke dalam harga pokok produksi. Sehingga biaya produksi tetap tersebut masih melekat pada produk yang belum terjual, dengan begitu tidak membebankan untuk kelangsungan bisnis selanjutnya dan pada periode cost. Sedangkan metode Variable costing ini merupakan metode penentuan harga pokok produksi yang hanya memasukkan biaya-biaya yang bersifat variabel ke dalam harga pokok produksi. Yang mana untuk biaya produksi tetap sendiri dianggap sebagai periode cost sehingga tidak ada biaya tetap yang belum dibebankan pada periode tersebut.

Perbedaan pokok antara metode Full costing dan Variable costing sebetulnya terletak pada perlakuan biaya tetap produksi tidak langsung. Dalam metode Full costing dimasukkan unsur biaya produksi karena masih berhubungan dengan pembuatan produk berdasar tarif (budget), 
sehingga apabila produksi sesungguhnya berbeda dengan budgetnya maka akan timbul kekurangan atau kelebihan pembebanan. Tetapi pada Variable costing memperlakukan biaya produksi tidak langsung tetap bukan sebagai unsur harga pokok produksi, tetapi lebih tepat dimasukkan sebagai biaya periodik, yaitu dengan membebankan seluruhnya ke periode dimana biaya tersebut dikeluarkan sehingga dalam Variable costing tidak terdapat pembebanan lebih atau kurang.

Adapun unsur biaya dalam metode Full costing terdiri dari biaya bahan baku, biaya tenaga kerja langsung dan biaya overhead pabrik baik yang sifatnya tetap maupun variabel. Sedangkan unsur biaya dalam metode Variable costing terdiri dari biaya bahan baku, biaya tenaga kerja langsung dan biaya overhead pabrik yang sifatnya variabel saja dan tidak termasuk biaya overhead pabrik tetap. (Hilton, 2001))

Akibat perbedaan tersebut mengakibatkan timbulnya perbedaan lain yaitu :

Dalam metode Full costing, perhitungan harga pokok produksi dan penyajian laporan laba rugi didasarkan pendekatan "fungsi". Sehingga apa yang disebut sebagai biaya produksi adalah seluruh biaya yang berhubungan dengan fungsi produksi, baik langsung maupun tidak langsung, tetap maupun variabel. Dalam metode Variable costing, menggunakan pendekatan "tingkah laku", artinya perhitungan harga pokok dan penyajian dalam laba rugi didasarkan atas tingkah laku biaya. Biaya produksi dibebani biaya variabel saja, dan biaya tetap dianggap bukan biaya produksi.Dalam metode Full costing, biaya periode diartikan sebagai biaya yang tidak berhubungan dengan biaya produksi, dan biaya ini dikeluarkan dalam rangka mempertahankan kapasitas yang diharapkan akan dicapai perusahaan, dengan kata lain biaya periode adalah biaya operasi. Dalam metode Variable costing, yang dimaksud dengan biaya periode adalah biaya yang setiap periode harus tetap dikeluarkan atau dibebankan tanpa dipengaruhi perubahan kapasitas kegiatan. Dengan kata lain biaya periode adalah biaya tetap, baik produksi maupun operasi.

Menurut metode Full costing, biaya overhead tetap diperhitungkan dalam harga pokok, sedangkan dalam Variable costing biaya tersebut diperlakukan sebagai biaya periodik. Oleh karena itu saat produk atau jasa yang bersangkutan terjual, biaya tersebut masih melekat pada persediaan produk atau jasa. Sedangkan dalam Variable costing, biaya tersebut langsung diakui sebagai biaya pada saat terjadinya. Jika biaya overhead pabrik dibebankan kepada produk atau jasa berdasarkan tarif yang ditentukan dimuka dan jumlahnya berbeda dengan biaya overhead pabrik yang sesungguhnya maka selisihnya dapat berupa pembebanan overhead pabrik berlebihan (over-applied factory overhead). Menurut metode Full costing, selisih tersebut dapat diperlakukan sebagai penambah atau pengurang harga pokok yang belum laku dijual (harga pokok persediaan).

Dalam metode Full costing, perhitungan laba rugi menggunakan istilah laba kotor (gross profit), yaitu kelebihan penjualan atas harga pokok penjualan. Dalam Variable costing, menggunakan istilah marjin kontribusi (contribution margin), yaitu kelebihan penjualan dari biaya-biaya variabel. (Horngren, Srikant, \& Madhav, 2015)

Beberapa hal yang perlu diperhatikan dari perbedaan laba rugi dalam metode Full costing dengan metode Variable costing adalah : (Mulyadi, 2009).Dalam metode Full costing, dapat terjadi penundaan sebagian biaya overhead pabrik tetap pada periode berjalan ke periode berikutnya bila tidak semua produk pada periode yang sama. Dalam metode Variable costing seluruh biaya tetap overhead pabrik telah diperlakukan sebagai beban pada periode berjalan, sehingga tidak terdapat bagian biaya overhead pada tahun berjalan yang dibebankan kepada tahun berikutnya. Jumlah persediaan akhir dalam metode Variable costing lebih rendah dibanding metode Full costing. 
Alasannya adalah dalam Variable costing hanya biaya produksi variabel yang dapat diperhitungkan sebagai biaya produksi.

Laporan laba rugi Full costing tidak membedakan antara biaya tetap dan biaya variabel, sehingga tidak cukup memadai untuk analisis hubungan biaya volume dan laba (CVP) dalam rangka perencanaan dan pengendalian. Menurut Hilton, Maher, \& Selto (2003) cara menghitung harga pokok produksi pada metode Full costing dan Variable costing adalah sebagai berikut :

Full Costing. Perhitungan harga pokok produksi pada metode Full costing terdiri dari:

1. Biaya bahan baku

2. Biaya tenaga kerja

3. Biaya overhead pabrik variabel

4. Biaya overhead pabrik tetap

5. Harga pokok produksi

Untuk mendapatkan harga pokok produksi maka menjumlahkan total dari biaya bahan baku, biaya tenaga kerja, biaya overhead pabrik variabel, dan biaya overhead pabrik tetap. Dimana sebelumnya untuk mencari biaya bahan baku, tenaga kerja, dan overhead pabrik variabel harus mengkalikan dengan jumlah unit produk yang diproduksi.

Selanjutnya dari perhitungan harga pokok produksi pada metode tersebut dilakukan pelaporan keuangan yang terdiri dari:

1. Hasil penjualan

2. Harga pokok produksi/penjualan

3. Laba kotor

4. Biaya pemasaran variabel

5. Biaya pemasaran tetap

6. Biaya administrasi dan umum variabel

7. Biaya administrasi dan umum tetap

8. Laba bersih

Yang mana untuk mendapatkan laba kotor, dapat dengan menghitung selisih antara hasil penjualan dan harga pokok produksi/penjualan. Sedangkan untuk mendapatkan laba bersih, dapat dengan menghitung selisih antara laba kotor yang telah didapatkan sebelumnya dengan jumlah total dari biaya pemasaran variabel yang telah dikalikan dengan unit produk yang terjual, biaya pemasaran tetap, biaya administrasi dan umum variabel serta biaya administrasi dan umum tetap.

\section{Variable Costing}

Setelah mengetahui perhitungan harga pokok produksi metode Full costing, maka selanjutnya adalah terkait cara perhitungan harga pokok produksi sebagai berikut:

1. Biaya bahan baku

2. Biaya tenaga kerja

3. Biaya overhead pabrik variabel

4. Biaya pokok produksi

Untuk mendapatkan biaya pokok produksi, dengan menjumlahkan biaya bahan baku, biaya tenaga kerja dan biaya overhead pabrik variabel yang telah dikalikan dengan jumlah unit produk yang diproduksi.

Selanjutnya untuk laporan keuangan dari metode Variable costing ini terdiri dari:

1. Hasil penjualan 
2. Biaya produksi variabel

3. Biaya pemasaran variabel

4. Biaya administrasi dan umum variabel

5. Marjin kontribusi

6. Biaya produksi tetap

7. Biaya pemasaran tetap

8. Biaya administrasi dan umum tetap

9. Laba bersih

Dimana untuk mendapatkan marjin kontribusi, hasil penjualan yang telah dikalikan dengan jumlah unit produk yang diproduksi dengan cara menghitung selisihnya dengan biaya produksi variabel dan biaya pemasaran varibel yang telah dikalikan dengan jumlah unit produk yang diproduksi. Kemudian untuk mendapatkan laba bersih, dapat dengan menghitung selisih antara marjin kontribusi dengan biaya produksi tetap, biaya pemasaran tetap dan biaya administrasi dan umum tetap.

Dari informasi dan cara perhitungan harga pokok produksi dengan menggunakan metode Full costing dan Variable costing di atas dapat dilihat bahwa metode Full costing semua biaya produksi diperhitungkan dalam harga pokok produksi. Akan tetapi akan ada biaya tetap yang belum dibebankan pada periode tersebut jika ada produk yang belum laku terjual, karena di dalam produk tersebut terdapat biaya overhead tetap yang melekat. Sedangkan metode Variable costing hanya memperhitungkan biaya-biaya produksi yang bersifat variabel dalam perhitungan harga pokok produksi. Dimana biaya tetap dianggap sebagai period cost dan langsung dibebankan pada periode yang bersangkutan.

Selain itu dalam penyajian laporan keuangan terkait laba rugi, metode Full costing dan Variable costing ini memiliki perbedaan. Pada metode metode Full costing, biaya overhead tetap yang dilaporkan dalam laporan laba rugi hanya biaya overhead tetap produk yang telah terjual saja pada periode tersebut. Sedangkan Variable costing, seluruh biaya overhead tetap yang terjadi dalam periode tersebut dilaporkan dalam laporan laba rugi perode tersebut sehingga akan mengurangi pendapatan pada periode tersebut.

\section{PENENTUAN HARGA POKOK PRODUK}

\begin{tabular}{|c|c|c|}
\hline Elemen biaya & Full costing & $\begin{array}{c}\text { Variable } \\
\text { costing }\end{array}$ \\
\hline $\begin{array}{l}\text { BBB(raw material cost) } \\
\text { BTKL(direct labor cost) } \\
\text { BOP variabel (variable FOH) } \\
\text { BOP tetap (fixed FOH) } \\
\text { Jumlah Harga Pokok Produk }\end{array}$ & $\begin{array}{l}\text { Rp.xxx } \\
\text { Rp.xxx } \\
\text { Rp.xxx } \\
\text { Rp.xxx } \\
\text { Rp. } x x x\end{array}$ & 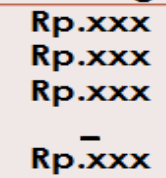 \\
\hline
\end{tabular}

Gambar 1. Contoh dan solusi yang diberikan kepada perusahaan

\section{HASIL DAN PEMBAHASAN}

Pelaksanaan kegiatan PKM dilakukan pada tanggal 21 \& 28 April 2018 bertempat di Gading Serpong Tangerang. Kegiatan penyuluhan dan pembinaan penyusunan Variable Costing ini dilakukan dengan urutan sebagai berikut: 
a. Survey lanjutan ke kantor PT Kapur Putih Lampung yang berlokasi di Gading SerrpongTangerang untuk mendapatkan kondisi riil dilapangan dan peserta yang akan mendapat penyuluhan.

b. Pembahasan dalam penentuan ruang lingkup materi

c. Pembinaan dan penyusunan variable costing masing-masing bagian baik manajemen, penjualan, produksi,keuangan dan Akuntansi.

d. Pembuatan dan mendiskusikan materi ajar yang akan dibagikan (Tim dosen)

e. Meminta konfirmasi waktu, jumlah materi kepada ke pihak perusahaan

f. Menggandakan materi penyuluhan

g. Melaksanakan penyuluhan

h. Evaluasi hasil penyuluhan dengan tim dosen

Hasil dari penyuluhan, pendampingan dan penyusunan variable costing sebagai alternative costing dalam penentuan harga produk telah selesai dilaksanakan memberikan dampak yang sangat positif karena perusahaan yang selama ini menerapkan full costing, mempunyai alternative pengambilan keputusan dengan metode variable costing. Seringkali proses produksi terdapat idle kapasitas karena keadaan ekonomi global yang lagi menurun dan serbuan barang-barang impor mengakibatkan berkurangnya order dari pelanggan dan stock perusahaan meningkat, mengakibatkan perputaran/kesulitan likuiditas perusahaan. Profit perusahaan mengalami penurunan karena kapasitas perusahaan yang sebenarnya masih tersedia di biarkan begitu saja oleh manajemen perusahaan.

Dengan alternative penerapan variable costing maka perusahaan mulai melakukan perubahan pola kerja dan memperhitungkan jika terdapat idle kapasitas produksi. Perusahaan menawarkan kepada pelanggan produk-produk diluar produk utama untuk diberikan promosi atau harga khusus yang sudah diperhitungan dengan metode variable costing (selama harga masih memberikan keuntungan setelah dikurangi dengan biaya-biaya variabel produk) maka perusahaan berani untuk mengambil keputusan untuk menjual produk tersebut. Hal ini terbukti memberikan peningkatan profit perusahaan, likuiditas keuangan perusahaan. Mereka merasakan manfaat dari pembinaan yang telah dilakukan sehingga meningkatkan pengendalian dan efisiensi pola kerja di internal perusahaan.
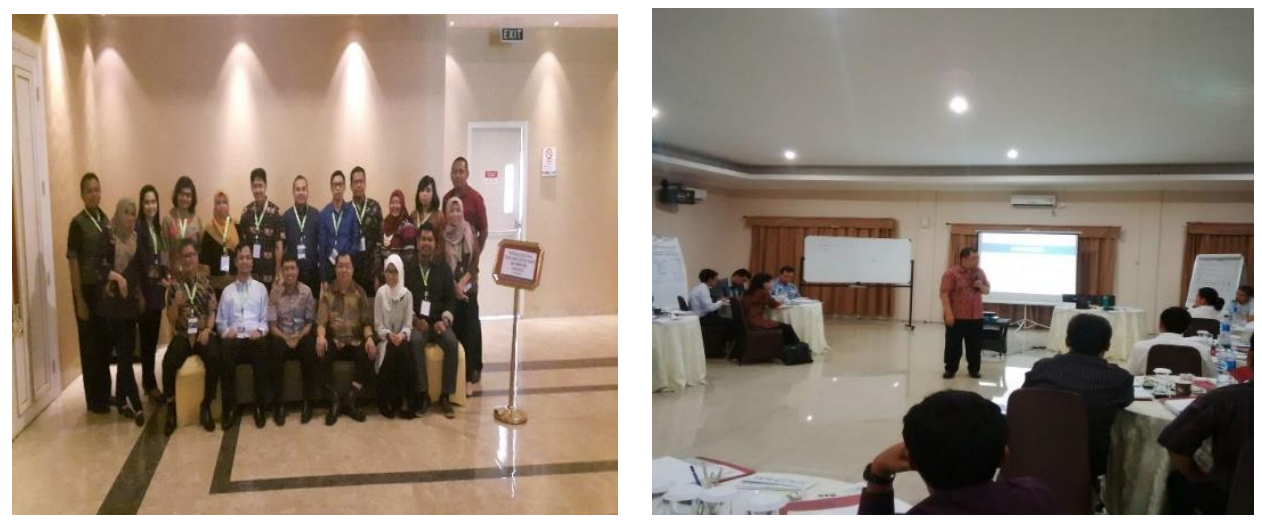

Gambar 2. Pelaksanaan kegiatan PKM

\section{KESIMPULAN DAN SARAN}

Aktifitas pembinaan dan penyuluhan ini sangat dirasakan manfaatnya bagi peserta maupun manajemen, hal ini dirasakan kemampuan perusahaan meningkatkan keuntungan dan likuiditas keuangan perusahaan dapat dilakukan perbaikan dan pembenahan. Pola kerja pengendalian kapasitas produksi dan kemampuan jual bagian marketing dapat lebih terkendali. Sistem 
pengawasan dan saling mengontrol antar bagian dan koordinasi antar bagian mulai terbentuk sesuai dengan kebijakan perusahaan. Kerapian dan keteraturan kerja dapat berjalan dengan lebih baik dibandingkan sebelumnya, walaupun masih terdapat kekurangan sana-sini di internal perusahaan karena baru tahap penyesuaian sistem kerja yang baru. Manajemen secara terukur dan pasti dapat mengawasi dan mengontrol aktifitas perusahaan, serta pengambilan keputusan yang cepat dan tepat.

Dengan membina dan memberikan masukan kepada perusahaan usaha kecil menengah, secara tidak langsung pihak akademisi ikut andil dalam menjaga roda perekonomian masyarakat.

\section{Ucapan Terima Kasih (Acknowledgement)}

Kami mengucapkan terima kasih kepada semua pihak yang telah mendukung terlaksananya kegiatan PKM ini yaitu Direktur Penelitian dan Pengabdian Kepada Masyarakat Universitas Tarumanagara selaku pihak yang mendukung dana dalam kegiatan PKM ini. Selain itu kami juga mengucapkan terima kasih kepada PT Kapur Putih Lampung yang telah memberi kepercayaan kepada kami untuk memberikan penyuluhan mengenai pengendalian internal dan audit internal.

\section{Referensi}

Garrison, Ray H., Nore en, Eric W., \& Brewer, Peter C.(2001). Akuntansi Manajerial. Jakarta :Salemba Empat.

Hilton, R. W., (2001).Managerial accounting: creating value in a dynamic business environment Fifth Edition, McGraw-Hill Irwin. 2001

Hilton, R. W., Michael W. Maher, \& Selto, F.H.(2003). Cost management: Strategies for business decisions . New York: McGraw - Hill Co, Inc

Horngren, Charles T., Srikant M. Datar,\& Madhav V. Rajan. (2015). Cost accounting: A managerial emphasis. 15 th edition, Pearson Education Ltd, Essex, 2015

Mulyadi. (2009). Akuntansi biaya . Yogyakarta: UPP STIM YKPN

Mulyadi, (2010). Akuntansi manajemen .Edisi 3. Jakarta : Salemba Empat. 